\title{
PENERAPAN PENDEKATAN SAINTIFIK BERBANTUAN POWERPOINT UNTUK MENINGKATKAN HASIL BELAJAR IPA POKOK BAHASAN CAHAYA DAN CERMIN
}

\author{
Albert Lumbu ${ }^{1)}$;Florentina Maria Panda ${ }^{2)}$ \\ ${ }^{1}$ FKIP Universitas Cenderawasih; albertlumbu@gmail.com \\ ${ }^{2}$ FKIP Universitas Cenderawasih; florentinapanda88@gmail.com
}

\begin{abstract}
Research has been conducted with the aim to find out (1) improvement of student learning outcomes by using a powerpoint-assisted scientific approach, (2) differences in student learning outcomes improvement between the use of scientific approaches and conventional approaches. This research method is quantitative research, with quasy experimental. The experimental design used was nonequivalent pretest-posttest control group design. The population is 450 students, namely class VIII semester II Jayapura State Junior High School. The sample used was class VIII H and VIII L with a total sample of 74 students. Sampling was used non-probability sampling technique by purposive sampling. Data on learning outcomes are collected through pretest and posttest. The instruments used are multiple choice tests that have been tested for validity, reliability, difficulty level, and distinguishing features. To find out the increase in student learning outcomes $n$-Gain is used. To see the difference in student learning outcomes improvement taught by a scientific approach assisted by PowerPoint and conventional approaches a statistical analysis of the different test (t-test) was conducted. The results showed that (1) learning with a scientific approach assisted by powerpoint media can improve the learning outcomes of experimental class students with a high category of 0.72 and a control class of 0.61. (2) there are differences in learning outcomes between the experimental class and the control class which indicated a significance value $\alpha<0.05$ which is equal to 0,000.
\end{abstract}

Keywords: Scientific Approach; Powerpoint; Light; Mirror

\begin{abstract}
ABSTRAK
Telah dilakukan penelitian dengan tujuan untuk mengetahui (1) peningkatan hasil belajar peserta didik dengan menggunakan pendekatan saintifik berbantuan powerpoint,(2) perbedaan peningkatan hasil belajar peserta didik antara penggunaan pendekatan saintifik dan pendekatan konvensional. Metode penelitian ini adalah penelitian kuantitatif, dengan quasy experimental. Desain eksperimen yang digunakan adalah nonequivalen pretest-posttest control group design. Populasi berjumlah 450 peserta didik yaitu kelas VIII semester II SMP Negeri Jayapura Tahun Sampel yang digunakan adalah kelas VIII H dan VIII L dengan jumlah sampel sebanyak 74 peserta didik. Pengambilan sampel digunakan teknik non probability sampling dengan cara purposive sampling. Data hasil belajar dikumpulkan melalui pretest dan posttest.Instrumen yang digunakan yaitu tes dalam bentuk pilihan ganda yang telah diuji validitas, reliabilitas, taraf kesukaran, dan daya pembeda. Untuk mengetahui peningkatan hasil belajar peserta didik digunakan n-Gain. Untuk melihat perbedaan peningkatan hasil belajar peserta didik yang diajarkan dengan pendekatan saintifik berbantuan powerpoint dan pendekatan konvensional dilakukan analisis statistik uji beda (uji-t). Hasil penelitian menunjukkan bahwa (1) pembelajaran dengan pendekatan saintifik berbantuan media powerpoint dapat meningkatkan hasil belajar peserta didik kelas eksperimen dengan kategori tinggi sebesar 0,72 dan kelas kontrol sebesar 0,61.(2) terdapat perbedaan hasil belajar antara kelas eksperimen dan kelas kontrol yang ditunjukkan nilai signifikansi $\alpha<0,05$ yaitu sebesar 0,000 .
\end{abstract}

Kata Kunci : Pendekatan Saintifik; Power point; Cahaya; Cermin. 


\section{PENDAHULUAN}

Fisika merupakan cabang IPA yang mendasari perkembangan teknologi maju dan konsep hidup harmonis dengan alam. Fisika merupakan mata pelajaran yang diajarkan pada setiap jenjang pendidikan di Indonesia mulai dari Sekolah Menengah Pertama (SMP) sampai Sekolah Menengah Atas (SMA). Pada tingkat SMA, fisika diajarkan dengan tujuan menumbuhkan kemampuan berpikir yang berguna untuk memecahkan masalah dalam kehidupan sehari-hari. Banyak peserta didik yang menganggap pelajaran fisika merupakan pelajaran yang sulit untuk dipahami, mengingat bahwa pelajaran fisika memiliki banyak teori-teori serta perhitungan sehingga hanya sebagian kecil peserta didik yang menyukai pelajaran fisika, sedangkan peserta didik yang lain tidak termotivasi untuk mengikuti pelajaran fisika. Dalam proses pembelajaran, guru hanya menggunakan model pembelajaran konvensional untuk menyampaikan materi yang diajarkan. Model pembelajaran seperti ini menyebabkan kurangnya keterlibatan peserta didik dalam proses pembelajaran didalam kelas melainkan hanya peserta didik yang memiliki kemampuan tinggi saja yang dapat mengikuti pelajaran dengan baik sedangkan peserta didik yang tidak memiliki kemampuan tinggi hanya menonton (pasif).
Berdasarkan hasil observasi yang dilakukan oleh peneliti di SMP Negeri 2 Jayapura terhadap hasil belajar peserta didik terungkap bahwa hasil belajar peserta didik yang berada diatas KKM (Kriteria Ketuntasan Minimal) lebih kecil dibandingkan hasil belajar yang berada dibawah KKM. Berdasarkan hasil survei pada kelas VIII H dan VIII L, peserta didik yang memiliki hasil belajar diatas KKM sebesar $32 \%$ (12 orang) dan $27 \%$ (10 orang) sedangkan peserta didik yang memiliki hasil belajar dibawah KKM 68\% (25 orang) dan sebesar $73 \%$ (27 orang).

Dalam hal ini pendidik memiliki peranan dan tanggung jawab yang sangat besar dalam pencapaian tujuan pembelajaran dan juga dipengaruhi oleh beberapa faktor, diantaranya adalah pendekatan pembelajaran yang diterapkan oleh seorang pendidik dan media pembelajaran untuk meningkatkan hasil belajar peserta didik haruslah sesuai dengan tujuan yang ingin dicapai, materi pelajaran, karakteristik mata pelajaran, dan dapat melibatkan kreativitas mental dan motorik yang bersifat ilmiah sehingga sangat berkaitan erat dengan pendekatan. Pendekatan yang dirasa mampu untuk membuat peserta didik lebih berani untuk bertanya, menjawab pertanyaan secara mandiri, dan melalui percobaan (eksperimen) peserta didik mampu menemukan sebuah konsep adalah 
Jurnal Ilmu Pendidikan Indonesia 8 (2) : 56 - $68 \mid 58$

pendekatan saintifik atau pendekatan ilmiah dimana pendekatan saintifik ini lebih menekankan peserta didik untuk mengkontruksi konsep, hukum atau prinsip melalui tahapan-tahapan seperti mengamati, merumuskan masalah, mengajukan atau merumuskan hipotesis, mengumpulkan data dengan berbagai teknik, menganalisis data, menarik kesimpulan, dan mengkomunikasikan konsep, hukum atau prinsip yang telah ditemukan, meskipun pada kurikulum 2013 pendekatan saintifik sudah diterapkan di SMA Negeri 5 Pontianak, namun guru pada mata pelajaran fisika masih belum secara efektif menggunakan pendekatan ini sehingga masih banyak peserta didik yang tidak tuntas pada mata pelajaran fisika ( Machin, 2014). Mata pelajaran fisika memiliki peran untuk mengembangkan sikap dan pola pikir ilmiah, logis dan rasional dalam kehidupan sehari-hari. Pembelajaran fisika dalam proses pembelajaran didalam kelas dapat disajikan menggunakan media sebagai alat untuk membantu guru dan peserta didik. Media tersebut dapat berupa powerpoint berbasis audio visual.

Berdasarkan uraian tersebut di atas, peneliti tertarik melakukan penelitian dengan judul "Penerapan Pendekatan Saintifik Berbantuan Powerpoint Untuk Meningkatkan Hasil Belajar IPA Fisika Pokok Bahasan Cahaya dan Cermin"

\section{METODE PENELITIAN}

Metode penelitian yang digunakan dalam penelitian ini adalah penelitian kuantitatif dengan metode eksperimen semu (Quasiexperimental Design). Peneliti membagi objek yang diteliti menjadi dua kelompok, yaitu kelompok eksperimen yang mendapatkan perlakuan dan kelompok kontrol yang tidak mendapatkan perlakuan. Penelitian ini menggunakan Nonequivalen Control Group Design dengan memberikan pretest dan posttest untuk mengukur hasil belajar. Penelitian ini dilakukan di kelas VIII semester genap tahun ajaran 2018/2019 SMP Negeri 2 Jayapura. Populasi dalam penelitian ini yaitu seluruh peserta didik kelas VIII SMP 2 Jayapura tahun ajaran 2018/2019 yang tersebar dari kelas VIII $^{\mathrm{A}}$ sampai dengan kelas VIII $^{\mathrm{L}}$ dengan jumlah total keseluruhan peserta didik yaitu 450. Teknik pengambilan sampel yang dipilih adalah purposive sampling. Berdasarkan teknik tersebut diperoleh kelas $\mathrm{VIII}^{\mathrm{H}}$ dan kelas VIII $^{\mathrm{L}}$ sebagai sampel dengan jumlah sebanyak 74 peserta didik. Penelitian ini terdapat dua variabel, yaitu Variabel Independent (bebas) dan Variabel Dependen (terikat). Variabel Independent (bebas) yaitu Pendekatan Saintifik berbantuan powerpoint dan Varibel Dependen (terikat) yaitu hasil belajar. Teknik pengumpulan data yang digunakan dalam penelitian ini yaitu tes pilihan ganda untuk mengukur hasil belajar. Tes hasil 
belajar digunakan untuk mengetahui skor peserta didik. Data tes awal dan tes akhir diolah untuk mendapatakan n-Gain. n-Gain dalam penelitian ini merupakan perubahan kemampuan yang dimiliki peserta didik setelah mengikuti pembelajaran pada konsep cahaya dan cermin. Data yang didapatkan dianalisis secara kuantitatif dengan menggunakan statistik parametrik untuk melihat perbedaan pendekatan saintifik berbantuan powerpoint antara kelas eksperimen dan kelas kontrol.

Uji prasyarat yang dilakukan meliputi uji normalitas dengan teknik Kolmogorov Smirnov dan uji homogenitas dengan menggunakan Uji $F$ varians. Setelah memenuhi uji prasyarat, dilanjutkan dengan uji hipotesis menggunakan uji independent sample t-test ( uji-t).

\section{HASIL DAN PEMBAHASAN}

\section{Hasil Analisis n-Gain Hasil Belajar \\ a. Hasil N-Gain Rata-Rata Hasil Belajar Tiap Konsep}

Hasil analisis n-Gain rata-rata hasil belajar tiap konsep diperoleh dari hasil pengolahan data pretest dan posttest tiap konsep pada kelas eksperimen dan kelas kontrol. Hasil n-Gain rata-rata peserta didik tiap konsep disajikan pada gambar 1:

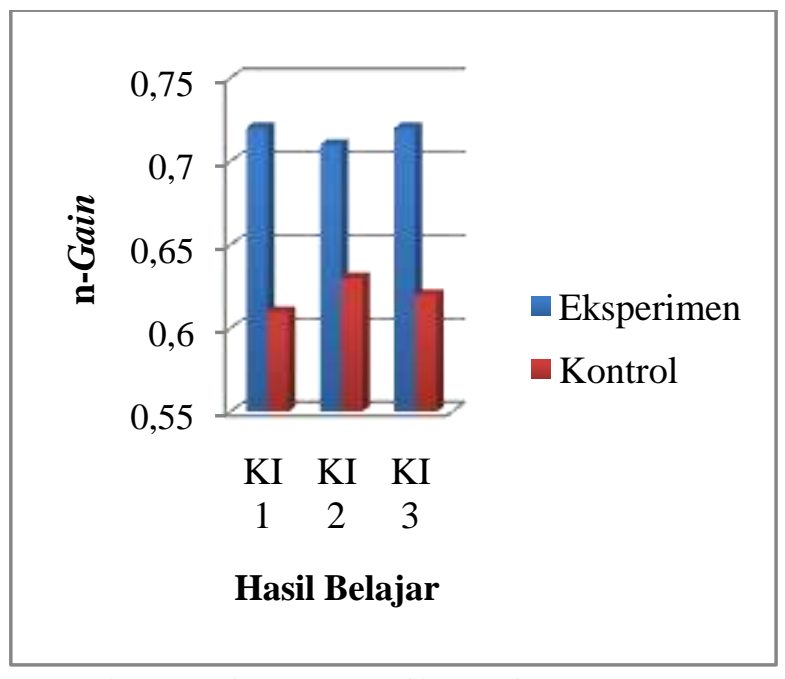

Gambar 1. Diagram Hasil n-Gain Rata-Rata Hasil Belajar Tiap Konsep

Keterangan :

K1 menyatakan Konsep Cahaya, K2 menyatakan Konsep Cermin Cekung dan K3 menyatakan Konsep Cermin Cembung.

Berdasarkan gambar 1 terlihat bahwa nilai $\mathrm{n}$-Gain hasil belajar untuk konsep cahaya pada kelas eksperimen 0,72 tergolong kategori tinggi dan pada kelas kontrol 0,61 tergolong kategori sedang. Terlihat pada kelas eksperimen terdapat 24 peserta didik termasuk dalam kategori nGain tinggi, 12 peserta didik termasuk dalam kategori n-Gain sedang dan 1 peserta didik termasuk dalam kategori nGain rendah. Pada kelas kontrol terdapat 14 peserta didik termasuk dalam kategori n-Gain tinggi, 19 peserta didik termasuk dalam kategori n-Gain sedang, dan 4 peserta didik termasuk dalam kategori nGain rendah.

Untuk peningkatan hasil belajar pada konsep cermin cekung, perolehan nGain kelas eksperimen 0,71 tergolong 
Jurnal Ilmu Pendidikan Indonesia 8 (2) : 56 - $68 \mid 60$

tinggi dan pada kelas kontrol 0,63 tergolong sedang. Terlihat pada kelas eksperimen terdapat 18 peserta didik termasuk dalam kategori n-Gain tinggi, 15 peserta didik termasuk dalam kategori nGain sedang dan 4 peserta didik termasuk dalam kategori n-Gain rendah. Pada kelas kontrol terdapat 14 peserta didik termasuk dalam kategori $\mathrm{n}$-Gain tinggi, 15 peserta didik termasuk dalam kategori n-Gain sedang, dan terdapat 8 peserta didik dalam kategori n-Gain rendah.

Pada konsep cermin cembung, kelas eksperimen 0,72 tergolong kategori tinggi dan pada kelas kontrol 0,62 tergolong kategori sedang. Terlihat pada kelas eksperimen terdapat 18 peserta didik termasuk dalam kategori n-Gain tinggi, 17 peserta didik termasuk dalam kategori nGain sedang dan terdapat 2 peserta didik termasuk dalam kategori n-Gain rendah. Pada kelas kontrol terdapat 12 peserta didik termasuk dalam kategori n-Gain tinggi, 16 peserta didik termasuk dalam kategori n-Gain sedang, dan 9 peserta didik termasuk dalam kategori n-Gain rendah. Karena nilai n-Gain tiap konsep pada kelas eksperimen lebih tinggi dibandingkan kelas kontrol, maka hasil belajar di kelas eksperimen lebih tinggi dibandingkan kelas kontrol.

Selisih dari peningkatan $\mathrm{n}-$ Gain pada tabel 1 konsep cahaya lebih tinggi dibandingkan dengan konsep kedua yaitu cermin cekung, konsep cahaya memiliki selisih $\mathrm{n}$-Gain sebesar 0,11 sedangkan konsep cermin cekung sebesar 0,08. Dalam hal ini berarti terjadi penurunan dari konsep pertama menuju konsep kedua. Hal ini disebabkan karena pada konsep pertama, peserta didik lebih mudah memahami konsep cahaya dibandingkan konsep cermin cekung yang baru mereka dapatkan di kelas VIII. Konsep cahaya telah mereka dapatkan sebelumnya di jenjang sekolah dasar, sehingga peserta didik sedikit kesulitan dalam memahami konsep cermin cekung. Pada konsep ketiga yaitu cermin cembung selisih $\mathrm{n}$-Gain sebesar 0,10 yang menandakan kembali terjadi peningkatan. Hal ini terjadi karena pada pembelajaran sebelumnya, peserta didik sudah belajar konsep cermin cekung yang konsepnya tidak jauh berbeda dengan cermin cembung, sehingga peserta didik sudah mulai memahami konsep pada materi cahaya dan cermin.

\section{b. Hasil n-Gain Rata-Rata Hasil Belajar Seluruh Konsep}

Hasil analisis $\mathrm{n}$-Gain rata-rata hasil belajar seluruh konsep diperoleh dari hasil pengolahan data pretest-posttest seluruh konsep pada kelas eksperimen dan kelas kontrol. Hasil n-Gain rata-rata peserta didik seluruh konsep disajikan pada gambar 2: 


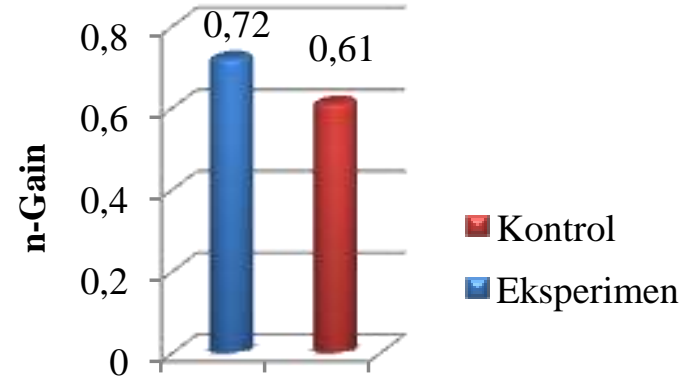

Hasil Belajar

Gambar 2. Diagram Hasil n-Gain Rata-Rata Hasil Belajar Seluruh Konsep

Berdasarkan gambar 2 dapat diketahui bahwa n-Gain rata-rata hasil belajar seluruh konsep cahaya dan cermin pada kelas eksperimen 0,72 dan n-Gain pada kelas kontrol 0,61. n-Gain hasil belajar pada kelas eksperimen tergolong kategori tinggi dan pada kelas kontrol tergolong kategori sedang. Melihat n-Gain pada kelas eskperimen lebih tinggi daripada $\mathrm{n}$-Gain kelas kontrol dengan selisih n-Gain 0,11 dapat disimpulkan bahwa hasil belajar peserta didik di kelas eksperimen lebih tinggi dibandingkan hasil belajar di kelas kontrol. Terlihat pada kelas eksperimen terdapat 20 peserta didik termasuk dalam kategori n-Gain tinggi, 17 peserta didik termasuk dalam kategori nGain sedang dan tidak terdapat peserta didik dalam kategori rendah. Pada kelas kontrol terdapat 9 peserta didik termasuk dalam kategori n-Gain tinggi, 28 peserta didik termasuk dalam kategori n-Gain sedang dan tidak terdapat peserta didik dalam kategori n-Gain rendah.

\section{Hasil Analisis Uji Beda Hasil Belajar}

\section{a. Hasil Uji Beda Tiap Konsep}

Untuk memperoleh hasil uji beda, terlebih dahulu lakukan uji normalitas untuk penggunaan analisis selanjutnya. Dalam pengujian normalitas, homogenitas dan uji beda peneliti menggunakan software SPSS 16.

Pengolahan uji normalitas untuk konsep cahaya diperoleh signifikan untuk kelas eksperimen 0,448 dan kelas kontrol 0,420. kedua kelas memiliki signifikan > 0,05, maka kedua kelas berdistribusi normal sehingga untuk uji beda dilakukan menggunakan Independent Sample Test. Dari hasil analisis diperoleh data memiliki varian sama (homogen) karena signifikan pada kolom Levene Statistic Test of Homogeneity of Variance> 0,05 yaitu sebesar 0,075. Untuk data homogen, perbedaan peningkatan hasil belajar peserta didik pada kelas eksperimen dan kelas kontrol dapat dilihat Sig. (2-tailed) pada kolom Equal variances assumsed < 0,05 yaitu sebesar 0,001. Sehingga disimpulkan bahwa terdapat perbedaan peningkatan hasil belajar antara kelas eksperimen dan kelas kontrol.

Hasil pengolahan uji normalitas untuk konsep cermin cekung diperoleh signifikan untuk kelas eksperimen 0,070 dan kelas kontrol 0,125. kedua kelas memiliki signifikan $>0,05$, maka kedua 
Jurnal Ilmu Pendidikan Indonesia 8 (2) : 56 - $68 \mid 62$

kelas berdistribusi normal sehingga untuk uji beda dilakukan menggunakan Independent Sample Test. Dari hasil analisis diperoleh data memiliki varian sama (homogen) karena signifikan pada kolom Levene Statistic Test of Homogeneity of Variance> 0,05 yaitu sebesar 0,351. Untuk data homogen, perbedaan peningkatan hasil belajar peserta didik pada kelas eksperimen dan kelas kontrol dapat dilihat Sig. (2-tailed) pada kolom Equal variances assumsed< 0,05 yaitu sebesar 0,034. Sehingga disimpulkan bahwa terdapat perbedaan peningkatan hasil belajar antara kelas eksperimen dan kelas kontrol.

\section{b. Hasil Uji Beda Seluruh Konsep}

Hasil pengolahan uji normalitas untuk seluruh konsep diperoleh signifikan untuk kelas eksperimen 0,515 dan kelas kontrol 0,456. kedua kelas memiliki signifikan >0,05, maka kedua kelas berdistribusi normal sehingga untuk uji beda dilakukan menggunakan Independent Sample Test. Dari hasil analisis diperoleh data memiliki varian sama (homogen) karena signifikan pada kolom Levene Statistic Test of Homogeneity of Variance> 0,05 yaitu sebesar 0,135. Untuk data homogen, perbedaan peningkatan penguasaan konsep peserta didik pada kelas eksperimen dan kelas kontrol dapat dilihat Sig. (2-tailed) pada kolom Equal variances assumsed $<0,05$ yaitu sebesar 0,000. Sehingga disimpulkan bahwa terdapat perbedaan peningkatan hasil belajar antara peserta didik yang mendapatkan pembelajaran dengan pendekatan saintifik berbantuan media powerpoint dan peserta didik yang mendapatkan pembelajaran dengan pendekatan konvensional.

Pembahasan hasil penelitian ini berdasarkan analisis data dan temuan di lapangan. Penelitian ini menggunakan pendekatan saintifik berbantuan media power point pada kelas eksperimen dan konvensional pada kelas kontrol. Pada kelas eksperimen menggunakan pendekatan saintifik berbantuan media power point karena pendekatan saintifik mampu membangun pengetahuan peserta didik melalui metode ilmiah. Begitupun dengan media pembelajaran sangat berpengaruh terhadap prestasi hasil belajar peserta didik. Melalui media power point memudahkan peserta didik untuk memahami materi dalam pembelajaran karena media powerpoint mampu menampilkan gambar, tabel, teks, animasi, danvideo yang bervariasi. Langkahlangkah pembelajaran dalam pendekatan saintifik terdapat 5 fase, yaitu: Mengamati, dalam fase ini peserta didik mengamati, mendengar, menyimak sebuah tayangan yang ditayangan dengan media power point. (2) Menanya, setelah peserta didik menyimak dan melihat tayangan yang telah ditampilkan didepan peserta didik dapat mengajukan pertanyaan 
tentang informasi yang tidak dipahami dari apa yang diamati atau pertanyaan untuk mendapatkan informasi tambahan tentang apa yang diamati. (3) Mengumpulkan data, peserta didik mengumpulkan informasi dari materi yang diajarkan oleh guru dengan melakukan eksperimen, membaca sumber lain seperti buku teks. (4) mengolah data, setelah peserta didik melakukan eksperimen untuk mendapatkan informasi atau data yang diinginkan peserta didik mulai mengolah data yang tepat dan relevan sesuai dengan apa yang dibutuhkan. (5) Mengkomunikasikan, perwakilan dari kelompok yang telah dibentuk oleh guru maju ke depan untuk mempresentasikan hasil yang telah didapatkan melalui eksperimen. Pendekatan saintifik menekankan peserta didik untuk mandiri dalam menemukan konsep pembelajaran sehingga peserta didik bukan hanya mampu memahami suatu konsep tetapi mampu menggunakan konsep dalam penyelesaian masalah.

\section{Peningkatan Hasil Belajar Tiap Konsep}

Pada pembelajaran pertama yaitu konsep cahaya jika ditinjau dari hasil penelitian yang dilakukan dan hasil analisis untuk melihat peningkatan hasil belajar peserta didik. Pada kelas eksperimen yang diajarkan menggunakan pendekatan saintifik berbantuan media power point mengalami peningkatan hasil belajar dalam kategori tinggi dan kelas kontrol yang diajarkan dengan pendekatan konvensional mengalami peningkatan hasil belajar dalam kategori sedang. Penerapan pendekatan saintifik berbantuan media power point mampu meningkatkan hasil belajar peserta didik yang ditunjukkan dengan hasil NGain konsep cahaya. Hal ini dikarenakan dengan media pembelajaran power point memungkinkan peserta didik terlibat aktif dalam mengembangkan pengetahuan, sikap dan keterampilannya sehingga peserta didik akan lebih mudah memahami materi fisika. Seperti halnya dalam penelitian Mufti (2016) bahwa pembelajaran yang menggunakan media power point peserta didik lebih tertarik dalam mengikuti proses belajar mengajar karena penyajiannya menarik, ada permainan warna, huruf, dan animasi. Sedangkan kelompok kontrol yaitu pembelajaran yang diajar tanpa menggunakan media power point peserta didik kurang tertarik dan guru lebih banyak mendominasi kegiatan belajar mengajar sehingga peserta didik cenderung pasif.

Pada pembelajaran yang kedua yaitu pada konsep cermin cekung peserta didik mengalami penurunan nilai n-Gain dibandingkan pada konsep cahaya. Hal ini dikarenakan konsep cermin cekung baru peserta didik dapatkan di kelas VIII ini, sehingga peserta didik merasa sedikit kesulitan untuk memahaminya. Pada kelas 
eksperimen yang diajarkan menggunakan pendekatan saintifik berbantuan media power point mengalami peningkatan hasil belajar dalam kategori tinggi dan kelas kontrol yang diajarkan dengan pendekatan konvensional mengalami peningkatan hasil belajar dalam kategori sedang. Berdasarkan dari hasil penelitian yang diperoleh mengenai hasil belajar peserta didik dengan menggunakan pendekatan saintifik berbantuan media power point dapat dijadikan salah satu alternatif pembelajaran yang dapat digunakan sebagai indikator dalam meningkatkan hasil belajar peserta didik baik ranah kognitif, afektif, dan psikomotorik.Sesuai dengan penelitian yang telah dilakukan $\mathrm{Ni}$ Luh Putu (2016) bahwa penerapan model mind mapping dalam pendekatan saintifik berbantuan media power point sangatlah tepat diterapkan pada pembelajaran guna mewujudkan pembelajaran yang menyenangkan, berkesan dan bermakna yang nantinya akan berimbas pada peningkatan hasil belajar peserta didik yang dalam hal ini khususnya hasil belajar pengetahuan IPA peserta didik, serta peningkatan prestasi belajar peserta didik baik pada aspek kognitif, afektif, dan psikomotor pada umumnya. Peningkatan hasil belajar terjadi karena pada pelajaran dengan menggunakan pendekatan saintifik peserta didik dituntut untuk berpikir secara mandiri, kemudian masalah dalam mengerjakan soal pada LKPD didiskusikan dengan teman kelompoknya sehingga dapat meningkatkan minat peserta didik untuk belajar fisika. Sesuai dengan penelitian Nasarullah (2015) yang menyatakan bahwa pembelajaran dengan menggunakan pendekatan saintifik mampu mendorong peserta didik belajar secara secara kreatif dan cenderung mengerahkan semua kemampuannya, sehingga pembelajaran yang dihasilkan dapat membuat hasil belajar fisika dari peserta didik dapat meningkat dan bermakna serta terserap secara merata.

Pada pembelajaran yang ketiga yaitu konsep cermin cembung ditinjau dari hasil penelitian untuk melihat peningkatan hasil belajar peserta didik. Pada kelas eksperimen yang diajarkan dengan menggunakan pendekatan saintifik berbantuan media power point mengalami peningkatan hasil belajar dalam kategori tinggi dan kelas kontrol yang diajarkan dengan pendekatan konvensional mengalami peningkatan hasil belajar dalam kategori sedang. Pada konsep ketiga ini peningkatan n-Gain kembali mengalami peningkatan, hal ini disebabkan karena peserta didik telah mulai terbiasa mendapatkan pembelajaran dengan pendekatan saintifik berbantuan media power point yang mendorong peserta didik untuk menyelesaikan masalah dan menemukan konsep materi secara mandiri. Peserta didik juga sudah mulai terbiasa 
dengan penyelesaian latihan-latihan soal yang diberikan.

\section{Peningkatan Hasil Belajar Seluruh Konsep}

Pembelajaran dengan menggunakan pendekatan saintifik berbantuan media power point memiliki peningkatan lebih tinggi dibandingkan dengan pembelajaran tanpa menggunakan media power point. Penerapan pembelajaran dengan berbantuan media power point bertujuan agar peserta didik dapat mengamati penyajian materi pembelajaran yang lebih menarik, tayangan seperti pembentukan bayangan pada cermin serta Hukum Snellius dapat dengan mudah ditampilkan dengan media tersebut dan dapat membantu peserta didik untuk lebih memahami materi pelajaran serta dapat membantu tercapainya tujuan dari kegiatan pembelajaran. Kecenderungan prestasi hasil belajar fisika pada kelas eksperimen yang pembelajarannya menggunakan media power point termasuk dalam kategori tinggi dibandingkan dengan hasil belajar pada kelas kontrol. Hal ini disebabkan karena dengan media pembelajaran power point memungkinkan peserta didik untuk terlibat aktif dalam mengembangkan pengetahuan, sikap, dan keterampilannya sehingga peserta didik akan lebih mudah memahami materi pelajaran fisika. Kelebihan pembelajaran dengan media power point adalah pembelajaran menjadi lebih menarik, pesan informasi secara visual sehingga lebih mudah dipahami, pembelajaran tidak monoton, penyajiannya menarik karena ada permainan warna,huruf, dan animasi. Sedangkan dalam pembelajaran tanpa menggunakan media power point, guru lebih banyak mendominasi kegiatan belajar dan cenderung pasif sehingga proses belajar mengajar menjadi membosankan dan tidak menarik bagi peserta didik. Dengan demikian peserta didik akan mengalami kesulitan dalam memahami pokok bahasan yang diajarkan. Hal ini sejalan dengan penelitian yang dilakukan Badrul (2015) bahwa pembelajaran menggunakan media power point menghasilkan prestasi belajar fisika yang lebih baik dibandingkan dengan pembelajaran menggunakan media konvensional.

\section{Perbedaan Peningkatan Hasil Belajar Tiap Konsep}

Berdasarkan hasil signifikansi uji beda diperoleh nilai t-hitung pada konsep cahaya sebesar 0,001 pada konsep cermin cekung diperoleh nilai t-hitung sebesar 0,034, dan pada konsep cermin cembung diperoleh nilai t-hitung sebesar 0,009. Hasil tersebut menunjukkan bahwa adanya perbedaan signifikan antara kelas eksperimen yang menggunakan pendekatan saintifik berbantuan media 
power point dan kelas kontrol yang menggunakan pendekatan konvensional dilihat dari angka signifikansi yaitu thitung $<0,05$. Pendekatan saintifik dapat menciptakan dan memfasilitasi kondisi belajar peserta didik pada materi cahaya dan cermin dengan memberikan kesempatan kepada peserta didik untuk melakukan kegiatan yang relevan sebanyak mungkin. Selain itu pendekatan saintifik dapat membuat peserta didik mencari informasi dan melatih memecahkan masalah melalui diskusi, sehingga terwujud pembelajaran yang aktif, efektif dan menyenangkan.

Pada saat proses pembelajaran konsep pertama yaitu cahaya dengan menggunakan pendekatan saintifik berlangsung peserta didik masih merasa asing dengan pendekatan tersebut, hal ini terlihat dari hasil refleksi yang menunjukkan bahwa guru masih harus menjelaskan langkah-langkah pembelajaran yang harus dilakukan peserta didik dan proses diskusi masih belum berjalan dengan rapi. Pada pembelajaran konsep cermin cekung dan cermin cembung, peserta didik sudah mulai terbiasa dengan pendekatan saintifik yang digunakan oleh guru. Rasa percaya diri peserta didik dalam mempresentasikan hasil diskusi dengan kelompok sudah mulai tumbuh. Pembelajaran dengan pendekatan saintifik dapat mempengaruhi hasil belajar peserta didik karena pendekatan pembelajaran ini menuntut peserta didik belajar untuk berbicara dan dapat bertukar pendapat melalui diskusi yang dilakukan. Hal tersebut sesuai dengan yang diungkapkan oleh Sudjana (2010) bahwa dengan menggunakan pendekatan yang tepat dapat membuat peserta didik kurang bisa menyampaikan dalam kelompok belajar seolah-olah dipaksa situasi untuk berbicara dalam kelompok kecil, menumbuhkan suasana yang akrab, penuh perhatian terhadap pendapat orang lain, dapat menghimpun berbagai pendapat orang tentang bagian-bagian masalah dalam waktu yang singkat, dan dapat digunakan bersama teknik lain sehingga teknik ini bervariasi.

\section{Perbedaan peningkatan Hasil Belajar Seluruh Konsep}

Dari hasil uji beda hasil belajar peserta didik ditunjukkan dengan hasil signifikan $<0,05$ yaitu sebesar 0,000 yang artinya terdapat perbedaan hasil belajar antara peserta didik yang mendapatkan pembelajaran dengan pendekatan saintifik berbantuan media power point pada kelas eksperimen dan peserta didik yang mendapatkan pembelajaran konvensional pada kelas kontrol. Nilai rata-rata kelas eksperimen lebih tinggi dibandingkan dengan nilai rata-rata kelas kontrol, maka dapat disimpulkan bahwa penggunaan pendekatan saintifik berbantuan media power point lebih efektif untuk 
meningkatkan hasil belajar peserta didik daripada pendekatan konvensional.

Pendekatan saintifik yang diterapkan pada materi cahaya dan cermin mampu mendorong peserta didik untuk memberikan sumbangan pemikirannya dalam proses pembelajaran, menciptakan suasana yang menyenangkan, dan memberikan variasi dalam kegiatan pembelajaran sehingga peserta didik tidak merasa bosan. Pendekatan saintifik mampu membuat peserta didik menjadi lebih mudah untuk memahami materi cahaya dan cermin, karena peserta didik terlibat secara langsung dalam mendapatkan ilmu pengetahuannya dengan cara berdiskusi dan saling bertukar pikiran. Hasil penelitian ini sesuai dengan penelitian Machin (2014) yang menyimpulkan bahwa salah satu cara unruk menciptakan pembelajaran yang bermakna adalah dengan menerapkan pendekatan saintifik. Selanjutnya, sesuai dengan penelitian Sujarwanta (2012) yang menyatakan bahwa pendekatan saintifik mengkaji caracara untuk mendapat pengetahuan baru yang dipelajari dengan menggunakan proses sistimatis. Penalaran deduktif dan induktif merupakan proses sistematis yang memadukan dua penalaran. Penggunaan pendekatan saintifik dalam pembelajaran membawa iklim berpikir rasional yakni mendasarkan kesimpulan pada kecerdasan, logika, dan bukti empirik. Suatu pendekatan berpikir dan berbuat yang diawali dengan mengamati dan menanya sampai kemudian mereka berupaya untuk mencoba, mengolah, menyaji, menalar, dan akhirnya mencipta. Itulah mengapa pendekatan saintifik ini akan bermuara ke tingkatan mencipta yang tentunya terdapat unsur kreativitas didalamnya.

\section{SIMPULAN DAN SARAN \\ SIMPULAN}

Pembelajaran dengan menggunakan pendekatan saintifik berbantuan media powerpoint dapat meningkatkan hasil belajar peserta didik pada pokok bahasan cahaya dan cermin. Peningkatan hasil belajar seluruh konsep pada kelas eksperimen yang diajarkan dengan menggunakan model PBL dengan $\mathrm{n}-\mathrm{Gain}$ sebesar 0,72 lebih tinggi dibandingkan pada kelas kontrol dengan n-Gain 0,61.

\section{SARAN}

Pendekatan saintifik berbantuan media powerpoint dapat digunakan untuk meningkatkan hasil belajar pada pokok bahasan cahaya dan cermin.

\section{UCAPAN TERIMA KASIH}

Ucapan terimakasih kepada Program Studi Pendidikan Fisika, Jurusan Pendidikan MIPA dan Fakultas Keguruan \& Ilmu Pendidikan yang telah membantu penulis dalam penyusunan artikel.

\section{DAFTAR PUSTAKA}

A.Machin, (2014), Implementasi Pendekatan Saintifik, Penanaman Karakter dan Konservasi pada 
Pembelajaran Materi Pertumbuhan. Jurnal Pendidikan IPA Indonesia vol.01, No.03, dipetik dari http://journal.unnes.ac.id/nju/index.ph p/jpii (diakses 15 Mei 2019 );

Badrul, W, (2015). Pemanfaatan Media Power Point Dalam Pembelajaran Fisika Dengan Pendekatan Kontruktivisme, Jurnal Pendidikan Fisika vol.03, No.02, hal, 34-42 dipetik dari ojs.fkip.ummetro.ac.id/index.php/fisik a (diakses 27 April 2019);

Mufti, Sumadi, (2016). Pengaruh Penerapan Media Power Point Dalam Pembelajaran Terhadap Prestasi Belajar Fisika Pokok Bahasan Listrik Dinamis. Jurnal Ilmiah Pendidikan Fisika vol 03, No.01, hal. 96-103 dipetik dari http://jurnal.ustjogja.ac.id/index.php/ ( diakses 26 April 2019);

Nasarullah, (2015), Upaya Meningkatkan Hasil Belajar Fisika Melalui Pendekatan Scientific Pada Peserta Didik Kelas VII/F SMP Negeri 1 Sungguminasa, Jurnal Pendidikan Fisika, vol.3, No. 01, hal, 95-104 dipetik darihttp://journal.uinalaudin.ac.id/indeks.php/PendidikanFi sika ( diakses 26 April 2019);

Ni Luh Putu, dkk. (2016), Model Mind Mapping Dalam Pendekatan Saintifik Berbantuan Media Powerpoint Untuk Meningkatkan Hasil Belajar Pengetahuan IPA, e-Journal PGSD Universitas Pendidikan Ganesha, vol.04, No.01, hal.1-10, https://ejournal.undiksha.ac.id/index.p hp/JJPGSD/article (diakses 26 April 2019);
Sudjana, (2010), Statistika Untuk Ekonomi dan Niaga, Bandung: Tarsito;

Sujarwanta, A, (2012), Mengkondisikan Pembelajaran IPA dengan pendekatan Saintifik. Jurnal Nuansa Kependidikan vol.16, No.01, hal.75-83 dipetik dari http://www.ac.id/file-jurnal/ (diakses 26 April 2019); 